\title{
Neurological Disorders among the Outpatients Living with Human Immuno Deficiency Virus (HIV) Following at the Parakou Hospital in 2014
}

\author{
Adoukonou Thierry, ${ }^{1,2}$, Agbétou Mendinatou ${ }^{1,2}$, Dassi Gbénou Jolianelle², Ahanhanzo Rhonel2, \\ Kpangon Arsene², Kossi Oyéné1,2, Agballa Gottfried², Dovonou Albert ${ }^{2}$, Houinato Dismand ${ }^{3}$
}

${ }^{1}$ Department of Neurology, Faculty of Medicine, University of Parakou, Parakou, Benin

${ }^{2}$ Department of Neurology, University Departmental Hospital of Parakou, Parakou, Benin

${ }^{3}$ Department of Neurology, Faculty of Health Sciences, Universitéy of Abomey-Calavi, Abomey-Calavi, Benin

Email: ^adoukonouthierry@yahoo.fr

How to cite this paper: Thierry, A., Mendinatou, A., Jolianelle, D.G., Rhonel, A., Arsene, K., Oyéné, K., Gottfried, A., Albert, D. and Dismand, H. (2019) Neurological Disorders among the Outpatients Living with Human Immuno Deficiency Virus (HIV) Following at the Parakou Hospital in 2014. Neuroscience \& Medicine, 10, 199-206.

https://doi.org/10.4236/nm.2019.103014

Received: May 17, 2019

Accepted: September 3, 2019

Published: September 6, 2019

Copyright $\odot 2019$ by author(s) and Scientific Research Publishing Inc. This work is licensed under the Creative Commons Attribution International License (CC BY 4.0).

http://creativecommons.org/licenses/by/4.0/

\begin{abstract}
Objective: To study the frequency of neurological disorders associated to HIV infection. Methods: This cross-sectional study was carried out from 16th June to 16th September 2014 and included all $289 \mathrm{HIV}$-outpatients admitted to the Parakou University hospital. All data were recorded, physical examination was performed and the medical sheet of each patient was assessed. The diagnosis of neurological disorder (central and peripheral) was based on clinical features, past medical history, biological test and CT-scan data after multidisciplinary staff. Epi-data and Epi-Info 6.04C were used to perform analysis. Results: They were $73(25.3 \%)$ male with a mean age of 38.0 years +/10.1 years. The mean duration of disease was 48.5 months $+/-37.1$ months. $150(51.9 \%)$ of them were at Stage 3 of the disease. All patients $(99.7 \%)$ were infected by HIV1, 188 (76.1\%) had CD4 cells at the onset of the follow-up less than 350 cells $/ \mathrm{mm}^{3}$ and $260(90.0 \%)$ were on ART. Among the 289 patients, 110 had at least one neurological disorder, the frequency of neurological disorders was $38.1 \%$. The main neurological disorders were peripheral neuropathy $(34.3 \%)$, isolated headache $(5.2 \%)$, stroke $(0.7 \%)$, cerebral toxoplasmosis $(0.7 \%)$ and one case of dementia $(0.7 \%)$. The main associated factors were the age of patient and exposure on neurotoxic drug, especially ART. Conclusion: The neurological disorders were more frequent among HIV patients with a high frequency of peripheral neuropathy probably due to ART.
\end{abstract}




\section{Keywords}

Neurological Disorders, HIV, AIDS, Peripheral Neuropathy, Epidemiology

\section{Introduction}

In sub-Saharan Africa, Human Immunodeficiency Virus (HIV) prevalence is 4.7\% [1]. According to the WHO, from 2000 to 2020, worldwide HIV-related deaths will be estimated at 68 million, including 55 million in Africa [2]. Since the discovery of the first case in 1985 in Benin, HIV/AIDS prevalence has grown exponentially and hovered around $1.1 \%$ in 2012 [3]. Neurological damage associated with HIV infection is common. In previous studies neurological disorders accounted for more than 50\% [4]. We reported previously $42.4 \%$ of the prevalence of distal sensory polyneuropathy among the HIV outpatients in Parakou [5]. In Bobo-Dioulasso at Burkina Faso Millogo and al reported 14\% of neurological disorders in HIV patients [6]. They can occur at all stages of HIV infection and can affect the central nervous system, as well as peripheral nervous system and muscle. This study was conducted with main objective to study the frequency and factors associated with neurological complications of HIV infection in people living with HIV followed ambulatory at CHUD-B/A in Parakou in 2014.

\section{Methods of Study}

Type of study and period of collection: This was a descriptive and analytical cross-sectional study with prospective data collection from 16 June to 16 September 2014.

Population of study is people living with HIV followed in ambulatory basis in consultation on the care site.

We included patient HIV positive, age more than 15 years old who had given their consent.

Criteria of exclusion were pregnant women infected with HIV and subject who was not able to answer questions.

Sampling was exhaustive with a size of 289 inclusive subjects.

The main dependent variable is neurological complication, whatever the type. After a clinical examination doing by the senior neurologist, study of file and after a validation in staff by a colleague of specialists (neurologist, internist, radiologist), a secondary endpoint is the type of neurological complication whose terms are $3=$ certain, $2=$ probable, $1=$ possible, $0=$ no neurological complication, $9=$ not researched. Table 1 shows the details of those data..

Data were collected with a standardized questionnaire during interview, observation (interrogation and physical examination doing by the senior neurologists) and document review (patient record).

Ethical considerations: authorization from the hospital management and the 
Table 1. Diagnostic criteria for different subtypes of neurological complications.

\begin{tabular}{|c|c|c|c|}
\hline $\begin{array}{l}\text { Main Neurological } \\
\text { Complications }\end{array}$ & Define Diagnosis & Probable Diagnosis & Possible Diagnosis \\
\hline Cerebral Toxoplasmosis & $\begin{array}{l}\text { Toxoplasma gondii isolation in a subject } \\
\text { with an intracranial expansive process } \\
\text { associated with an infectious syndrome }\end{array}$ & $\begin{array}{l}\text { - Intracranial expansive process } \\
\text { - } \text { Fever } \\
\text { - } \text { Image in cockade on the } \\
\text { scanner } \\
\text { - } \quad \text { Good therapeutic response }\end{array}$ & $\begin{array}{l}\text { - Intracranial expansive process } \\
\text { - } \text { Fever } \\
\text { - } \text { Image in cockade on the } \\
\text { scanner } \\
\text { - } \quad \text { Good therapeutic response }\end{array}$ \\
\hline Peripheral Neuropathy & $\begin{array}{ll}\text { - } & \text { Paresthesia/Frank pain } \\
\text { - } & \text { Sensory syndrome } \\
\text { - } & \text { Peripheral neurogenic syndrome } \\
& \text { with or without } \\
\text { - } & \text { EMG confirmation of peripheral } \\
& \text { nervous system involvement }\end{array}$ & $\begin{array}{l}\text { - Sensory syndrome } \\
\text { - Paresthesia or frank pain }\end{array}$ & $\begin{array}{r}\text { Paresthesia or frank pain of } \\
\text { evolution less than a month }\end{array}$ \\
\hline Bacterial Meningitis & $\begin{array}{l}\text { Clinical picture of meningitis } \\
\text { Isolation of a germ on direct } \\
\text { examination or culture }\end{array}$ & $\begin{array}{l}\text { Clinical signs of meningitis } \\
\text { Favorable evolution under } \\
\text { antibacterial }\end{array}$ & \\
\hline Dementia & $\begin{array}{l}\text { Cognitive disorders of progressive } \\
\text { installation with significant } \\
\text { repercussions on the social life of the } \\
\text { individual } \\
\text { DSM-IV Criteria }\end{array}$ & $\begin{array}{l}\text { Progressive impairment of } \\
\text { cognitive functions } \\
\text { (more than two functions) } \\
\text { Impact on social life }\end{array}$ & \\
\hline Stroke & $\begin{array}{l}\text { Presumed vascular sudden neurological } \\
\text { deficiency confirmation by a CT scan }\end{array}$ & $\begin{array}{l}\text { Vascular presumptive brutal } \\
\text { neurological deficit without } \\
\text { any other immediately } \\
\text { identifiable cause }\end{array}$ & \\
\hline Isolated Headache & $\begin{array}{l}\text { Persistent headache } \\
\text { Absence of obvious etiologies } \\
\text { Absence of fever }\end{array}$ & & \\
\hline
\end{tabular}

head of medicine department was obtained prior to the study. Free and informed consent of each participant was obtained prior to inclusion. Confidentiality, rules of courtesy and discretion were respected.

Data were analysed with EPI DATA, EPI-INFO and SPSS (Statistical Package for Social Sciences) version 17.0. The quantitative variables were expressed in averages (in case of normal distribution) with their standard deviation, and qualitative variables were expressed in proportion with their confidence interval at $95 \%$. The proportions were compared with the test of chi-square $\left(\mathrm{Khi}^{2}\right)$ or exact test of Fischer and the means were compared by using Students' T-test. Statistical significance level was $5 \%$.

\section{Results}

\subsection{Sociodemographic Characteristics}

The site of managment of person living with HIV of University hospital of Parakou had an active line of 1100 patients at the start of the study. During the three months of the survey, a total of 334 persons living with HIV had consulted and 289 were included with the participation rate of $86.52 \%$. The mean age was 
$38.0 \pm 10.1$ years $(21-74$ years). They were 112 patients of 35 to 45 years (38.8\%), 73 male (25.3\%) and 216 female (74.7\%) with sex ratio of $0.3 ; 194$ lived in couple $(67.1 \%)$ and the majority were traders $111(38.4 \%)$ or craftsmen 58 (20.1\%). Nevertheless, we found 8 students $(2.8 \%)$ among the persons living with HIV. More than one third of the patients were illiterate $109(37.7 \%)$. Among the educated patients, 96 (33.2\%) had primary academic level and 12 (4.2\%) had higher academic level.

\subsection{Clinical Characteristics}

According to the WHO stages, twenty six percent of patients were in stage 1 of HIV infection; $15.6 \%$ in stage $2 ; 51.9 \%$ in stage 3 and $6.6 \%$ in stage 4 . The mean duration of HIV infection was 48.51 months \pm 37.13 months with a maximum of 197 months. Personal history of alcohol intake (27.3\%), tobacco (2.8\%), shingles (17.0\%), hypertension $(4.5 \%)$ and diabetes $(0.7 \%)$ had been noted. One hundred and one patients (37.7\%) were taken neurotoxic drugs including 96 under Stavudine, 10 under Isoniazide and 3 under Didanosine. The main reason for consultation was a neurological sign in $6.6 \%$ of cases (19 patients); the neurological signs are summarized in Table 2.

Thus 16 patients had a sensory syndrome (5.5\%), 10 patients a peripheral neurogenic syndrome (3.5\%), 1 patient a dementia (0.3\%), 1 patient a meningitis syndrome $(0.3 \%)$ and 1 patient an intracranial hypertension syndrome $(0.3 \%)$.

Table 2. Distribution of neurological signs in people living with HIV, Parakou 2014.

\begin{tabular}{|c|c|c|}
\hline Neurological Signs & Number & Percentage\% \\
\hline Cognitive Memory Disorder & 1 & 0.4 \\
\hline Post-Zoster Algies & 12 & 4.2 \\
\hline Peripheral Facial Paralysis & 1 & 0.4 \\
\hline Motor Deficit of Both Pelvic Limbs & 1 & 0.4 \\
\hline Language Trouble & 1 & 0.4 \\
\hline Tremor & 1 & 0.4 \\
\hline Motor Deficiency of a Hemicorp & 2 & 0.7 \\
\hline Difficulty Walking & 5 & 1.7 \\
\hline Spinal Pain & 1 & 0.4 \\
\hline Pain of the Lower Limbs & 20 & 6.9 \\
\hline Tingling of the Lower Limbs & 27 & 9.3 \\
\hline Burns of the Lower Limbs & 27 & 9.3 \\
\hline Persistent Headaches & 28 & 9.7 \\
\hline Numbness of the Lower Limbs & 30 & 10.4 \\
\hline Other Paresthesias of the Members* & 32 & 11.1 \\
\hline Total & 289 & \\
\hline
\end{tabular}


Two hundred and eighty eight patients (99.7\%) were infected with HIV 1 and only one patient $(0.3 \%)$ with HIV 2. An initial CD4 count less than 350 cells $/ \mathrm{mm}^{3}$ was found in 188 patients $(76.1 \%)$; 34 patients $(13.8 \%)$ had an initial CD4 count between 350 and 500 cells $/ \mathrm{mm}^{3}$ and 25 patients (10.1\%) greater than 500 cells $/ \mathrm{mm}^{3}$.

Two hundred and seventy nine $(96.5 \%)$ of patients were taking bactrim prophylaxis; 260 (90\%) were on antiretroviral therapy. The therapeutic regimens are summarized in Table 3.

AZT $=$ Zidovudine, $3 \mathrm{TC}=$ Lamivudine, EFV = Efavirenz, NVP = Nevirapine, $\mathrm{ABC}=$ Abacavir, $\mathrm{TDF}=$ Tenofovir, $\mathrm{LPV} / \mathrm{r}=$ Lopinavir $/$ Ritonavir.

\subsection{Neurological Complications and Factors Associated}

The frequency of neurological complication was $38.1 \%$ (110 patients). Diagnosis of these complications was probable in $12.2 \%$, possible in $2.8 \%$ and certain in $19.4 \%$ of cases. They are summarized in Table 4.

The factors associated to the neurological complications were: age with a frequency of complications at $26 \%$ in the $25-34$ years group and $49.3 \%$ in the $>45$ years group $\left(\mathrm{Chi}^{2}=15.53 ; \mathrm{p}=0.0014\right)$; and neurotoxic treatments $(\mathrm{p}=$ $\left.0.018 \mathrm{Chi}^{2}=5.53\right)$. ART $(\mathrm{p}=0.5351)$ and the CD4 cells count $(\mathrm{p}=0.76)$ were not statistically associated with the frequency of neurological complications. Nevertheless, the mean CD4 count in patients with toxoplasmosis was 190 cells $/ \mathrm{mm}^{3}$ and 310.5 cells $/ \mathrm{mm}^{3}$ in patients with peripheral neuropathy.

Table 3. Distribution of people living with HIV according to ART protocol established, Parakou 2014.

\begin{tabular}{ccc}
\hline HAART Protocol & Number & Percentage (\%) \\
\hline AZT + 3TC + EFV & 98 & 37.7 \\
$\mathrm{AZT}+3 \mathrm{TC}+\mathrm{NVP}$ & 78 & 30 \\
$\mathrm{TDF}+3 \mathrm{TC}+\mathrm{EFV}$ & 73 & 28.1 \\
$\mathrm{TDF}+3 \mathrm{TC}+\mathrm{NVP}$ & 4 & 01.5 \\
$\mathrm{TDF}+\mathrm{ABC}(3 \mathrm{TC})+\mathrm{LPV} / \mathrm{r}$ & 7 & 02.7 \\
Total & 260 & 100 \\
\hline
\end{tabular}

Table 4. Neurological complications in people living with HIV, Parakou 2014.

\begin{tabular}{ccc}
\hline Neurological Complications & Number & Percentage (\%) \\
\hline Peripheral Neuropathies & 99 & 34.3 \\
Persistent Headaches & 15 & 5.2 \\
Stroke & 2 & 0.7 \\
Dementia & 1 & 0.3 \\
Toxoplasmosis & 1 & 0.3 \\
Bacterial Meningitis & 1 & 0.3 \\
Total & 289 & \\
\hline
\end{tabular}




\subsection{Time of Onset of Neurological Complications According to the Duration of HIV Infection and CD4 Cells Count (Figure 1)}

Persistent headaches are the first neurological manifestations that appear on average at 42 months after the discovery of HIV infection.

Persistent headaches, dementia and neuropathies are the first neurological manifestations that appear after ARV therapy. Their mean time to onset was 37 months, 41 months and 47 months respectively after ART.

The comparison of average duration of infection, mean duration of ART, mean CD4 count and mean age according to neurological or non-neurological complications is summarized in Table 5. The patients with neurological disorders were elder than those without neurological disorders and had a long duration of the disease.

\section{Discussion}

Patients were young, as patients living with HIV in sub-Saharan Africa [6]. However, the prevalence of neurological complications increased with age in this study. Average age of patients with neurological complications 40.7 years

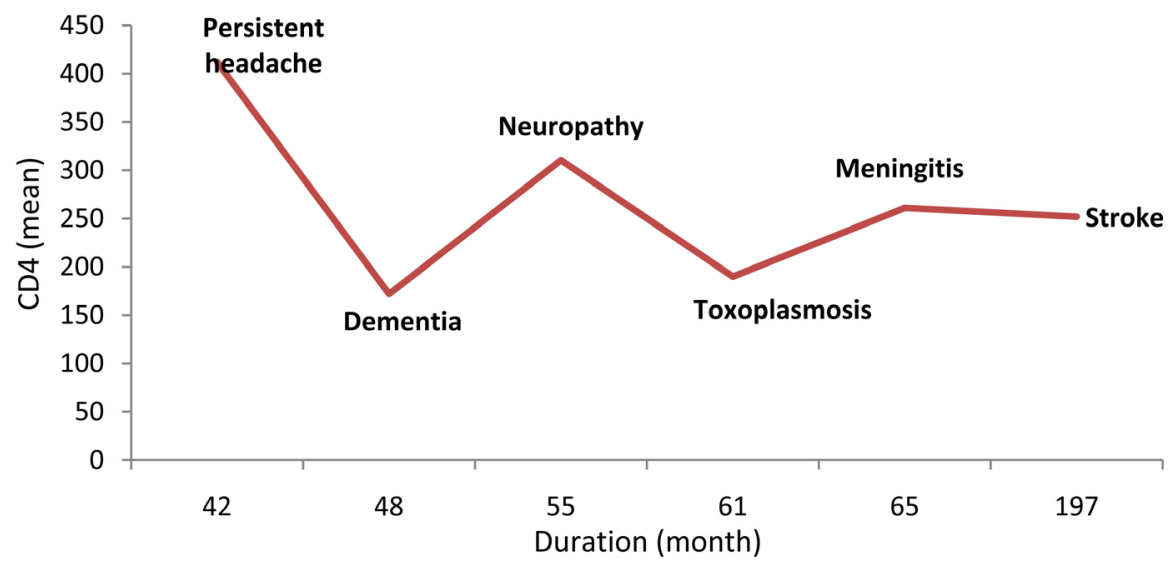

Figure 1. Neurological manifestations of HIV according to the duration of the disease and CD4, Parakou 2014.

Table 5. Comparison of average duration of infection, mean duration of ART, mean CD4 count and mean age according to neurological or non-neurological complications, Parakou 2014.

\begin{tabular}{cccc}
\hline & $\begin{array}{c}\text { Neurological Complications } \\
\text { Mean }(+/- \text { Standard Deviation })\end{array}$ & $\begin{array}{c}\text { No-Neurological Complications } \\
\text { Mean }+ \text { - Standard Deviation) }\end{array}$ & $\mathrm{p}^{*}$ \\
\hline $\begin{array}{c}\text { Duration of the Disease } \\
\text { (Months) }\end{array}$ & $53.2(37.1)$ & $45.6(37.0)$ & 0.09 \\
$\begin{array}{c}\text { Duration on HAART } \\
\text { (Months) } \\
\text { CD4 Cells Count }\end{array}$ & $45.6(30.7)$ & $44.6(34.5)$ & 0.81 \\
Age (Years) & $341.2(182.2)$ & $357.8(183.8)$ & 0.76 \\
\hline
\end{tabular}

* Student's t-test. 
significantly higher than those without neurological complications 36.6 years $(p=0.005)$. This suggests that aging promotes neurological complications. The frequency of neurological complications is higher compared with another in the subregion and elsewhere; $14.7 \%$ in Burkina Faso [6] and 7.94\% in Tehran in 2014 [7]. Prevalence of neurological complications in our patients is mainly related to the use of neurotoxic drugs, especially stavudine, which is the most widely used molecule. In our study, stage of HIV is not associated with neurological complications, and the proportion of patients with neurological complications is not statistically different from the proportion of other patients. Polyneuropathy (PN) is due to longer duration of infection, uncontrolled viremia, and exposure to older ARV including d4T, ddI and ddC [8] but new regimens suggest a stability of $\mathrm{PN}$ prevalence over time [9]. These are the most frequent neurological complications $(34.26 \%)$ in our patients. Millogo in Burkina Faso had noted a frequency around 37\% [6] and Wateba in Togo 30.7\% [10]. These neurological manifestations occur more than 4 years and a half in the course of the disease, and their only imputability to neurotoxicity by stavudine or to HIV remains debatable in lack of electroneuromyographic exploration and nerve biopsy. The frequency of cerebral toxoplasmosis is low in this population, as they were included only in consultation and the majority of our patients were on cotrimoxazol prophylaxis (96.5\%). Both HIV infection and ART could potentially increase an individual's risk of stroke [11]. In France, its incidence is 1.1 per 1000 person-years (Male $=1.4$ Female $=0.5)$ [12]. In this study, stroke occurred more late in the course of the disease (197 months) with a lower freqency $0.7 \%$ but justify systematic HIV test in all cases of stroke, especially in developing countries such as ours. Isolated headaches are the second most common complication in our patients; probably because of the side effects of ART mainly AZT used in most patients (67.9\%).

\section{Conclusion}

The frequency of neurological complications in people living with HIV aged 15 years and over followed by outpatient visits in Parakou CHUDB in 2014 is $38.1 \%$. A predominance of peripheral neuropathies was noted. Clinical, electrophysiological and therapeutic cohort studies are needed to better monitor this population in our country.

\section{Conflicts of Interest}

The authors declare no conflicts of interest regarding the publication of this paper.

\section{References}

[1] Rozenbaum, W. (2001) Guide de l'infection à VIH. Impact médecine, Paris.

[2] Moulignier, A. (2007) Le complexe démentiel associé au VIH: Aspects particuliers chez les sujets âgés. Psychologie et neuropsychiatrie du vieillissement, 5, 193-207. 
[3] ONUSIDA (2013) Rapport ONUSIDA sur l'épidémie mondiale de sida.

[4] McArthur, J.C., Brew, B.J. and Nath, A. (2005) Neurological Complications of HIV Infection. The Lancet Neurology, 4, 543-555. https://doi.org/10.1016/S1474-4422(05)70165-4

[5] Adoukonou, T.A., Kouna-Ndouongo, P., Kpangon, A., Gnonlonfoun, D., Kpacha, B., Dovonou, A. and Houinato, D. (2017) Distal Sensory Polyneuropathy among HIV-Infected Patients at Parakou University Hospital, Benin, 2011. Médecine et Santé Tropicales, 27, 190-194. https://doi.org/10.1684/mst.2017.0685

[6] Millogo, A., Ki-Zerbo, G.A., Sawadogo, A.B., Ouedraogo, I., Yameogo, A., Tamini, M.M., et al. (1999) Manifestations neurologiques associées à l'infection par le VIH au Centre hospitalier de Bobo-Dioulasso (Burkina Faso). Bulletin de la Société de Pathologie Exotique, 92, 23-26.

[7] Mohraz, M., Bayat, Z., Behtaj, M., Shooka, E., Seyedalinaghi, S., Jabbari, H., et al. (2014) Neurological Manifestations in HIV Positive Patients in Tehran, Iran. Asian Pacific Journal of Tropical Disease, 4, S481-S485.

https://doi.org/10.1016/S2222-1808(14)60494-1

[8] Chen, H., Cliffordb, D.B., Deng, L.J., Wu, K.L., Lee, A.J., Bosch, R.J., et al. (2013) Peripheral Neuropathy in ART-Experienced Patients: Prevalence and Risk Factors. Journal of Neuro Virology, 19, 557-564. https://doi.org/10.1007/s13365-013-0216-4

[9] Evans, S.R., Ellis, R.J., Chen, H., Yeh, T., Lee, A.J., Schifitto, G., et al. (2011) Peripheral Neuropathy in HIV: Prevalence and Risk Factors. AIDS, 25, 919-928. https://doi.org/10.1097/QAD.0b013e328345889d

[10] Wateba, M.I., Fiogbe, A., Assogba, K. and Tidjani, O. (2013) Prévalence des neuropathies périphériques (NP) et leurs facteurs associés chez les patients sous traitement antirétroviral suivis dans le service des Maladies infectieuses du CHU sylvanus olympio de Lomé. Cames Sante, 1, 24-27.

[11] Benjamin, L.A., Bryer, A., Emsley, H.C.A., Khoo, S., Solomon, T. and Connor, M.D. (2012) HIV Infection and Stroke: Current Perspectives and Future Directions. The Lancet Neurology, 11, 878-890. https://doi.org/10.1016/S1474-4422(12)70205-3

[12] De Broucker, T. (2013) Complications neurologiques par le virus de l'immunodéficience humaine (VIH). Pratique Neurologique-FMC, 4, 213-228. https://doi.org/10.1016/j.praneu.2013.10.002 